\title{
THE SHARIA SUPERVISORY BOARD AND CORPORATE SOCIAL RESPONSIBILITY DISCLOSURE: A SHARIA PERSPECTIVE IN INDONESIA
}

\author{
Winarsih Winarsih ${ }^{1^{*}}$, Robiyanto Robiyanto ${ }^{2}$ \\ ${ }^{1}$ Assistant Professor, Department of Accounting, Faculty of Economics and Business, Sultan Agung Islamic University, \\ Jl. Kaligawe Raya KM.4, Semarang 50112, Central Java, Indonesia, ${ }^{2}$ Assistant Professor, Department of Management, \\ Faculty of Economics and Business, Satya Wacana Christian University, Jl. Diponegoro No. 52-60, Salatiga 50711, \\ Indonesia. \\ Email: ${ }^{1 *}$ winarsih@unissula.ac.id, ${ }^{2}$ robiyanto@staff.uksw.edu
}

Article History: Received on $17^{\text {th }}$ December 2019, Revised on $02^{\text {nd }}$ February 2020, Published on $29^{\text {th }}$ February 2020

\begin{abstract}
Purpose of the study: This research aims to examine the relationship between the Sharia Supervisory Board (SSB) and the Corporate Social Responsibility (CSR) disclosure with financial performance as a mediating variable in Indonesia. By understanding the importance of the SSB responsibilities in the continuity of Sharia Banks, therefore, it is necessary to reexamine them.

Methodology: This research was conducted on sharia banks registered in Sharia Banking Statistics of the Financial Services Authority (Otoritas Jasa Keuangan (OJK) in Bahasa) during the period of 2010-2016. There were 6 Sharia Banks involved as the sample of this study selected through a purposive sampling technique.

Main Findings: The results showed that the Sharia Supervisory Board had a positive relationship with the CSR disclosure. But, this study implies that the CSR disclosure is not able to mediate the relationship between the SSB with the CSR disclosure of sharia banks in Indonesia.

Applications of this study: In Indonesia, the purpose of existence of the SSB in Sharia Banks is to tend to comply with regulation, and this condition may affect the results. So, some measurement about the SSB in Indonesia is needed in future studies. Also, for future studies, it is suggested that they may add quality assets as a proxy for financial performance and other variables in order to obtain better results.

Novelty/Originality of this study: This study tries to prove empirically the relationship between the SSB on the CSR disclosure of Sharia Banks in Indonesia with financial performance as its mediating variable. This study is indispensable to do in Indonesia, as the country with the biggest Muslim population in the world.
\end{abstract}

Keywords: Corporate Social Responsibility Disclosure, ISR Index, Sharia Supervisory Board, Financial Performance.

\section{INTRODUCTION}

The sharia-based business entities such as sharia banking have a foothold in implementing and disclosing corporate social responsibility (CSR) activities, as regulated in "Act of the Republic of Indonesia Number 21 of 2008 Concerning Sharia (Islamic) Banking" 2008). The regulation states that sharia banks and Sharia Business Unit (Unit Usaha Syari'ah (UUS) in Bahasa) can perform social functions in the form of giving zakat, infaq, alms or other social funds and deliver them to the organizations of zakat management. They can also raise money and distribute them to the management (nazhir) in accordance with the will of the waki. Sharia banking in carrying out operational activities will form Baitul Maal to manage the CSR, charity, alms, and qard hassan (loans without profit).

The CSR in a sharia perspective is a consequence of Islam, and the objective of Sharia law (Maqasid al sharia) is maslahah, so the business is an effort to create maslahah and has a position of great depth and one way to reduce problems in society. Islam requires the circulation of wealth to occur in all members of society and prevent wealth circulation only in some people. Allah (Subhanahu Wa Ta'ala (SWT), or Glorify to Him, the Exalted) says: "...so that it will not be a perpetual distribution among the rich from among you."(The Holy Qur'an, 59:7).

The practice of CSR in Islam emphasizes the ethics of Sharia business. The operational companies must be free from various modes of corruption (fight against corruption)and provide maximum service guarantee throughout its operational place, including trusted services for each product(provision and development of safe and reliable products) (Muharam, Anwar, \& Robiyanto, 2019; Robiyanto, Santoso, \& Ernayani, 2019; Wahyudi, Nofendi, Robiyanto, \& Hersugondo, 2018). This is explicitly stated in the Qur'an. Allah (SWT) says"...so fulfill the measure and weight and do not deprive people of their due and cause not corruption upon the earth after its reformation..." (The Holy Qur'an, 7:85).

In addition to emphasizing social activities in society, Islam also orders CSR practices on the environment. The environment and preservation are some of the main teachings of Islam. The fundamental principles shaped the philosophy of environmental virtue performed holistically by the Prophet Muhammad (Sall'Allahu Alayhi Wasalam (SAW), or Peace Be Upon Him (PBUH)) is the belief in the existence of interdependence among God's creatures. Allah (SWT) creates this universe measurably, both quantitative and qualitative (The Holy Qur'an, 54:49) and in balanced condition (Surah Al Hadid: 7). From this principle, the consequence is if humans corrupt or neglect one part of Allah (SWT)'s creation, then 
nature as a whole will experience suffering which in the end will also harm a human. Allah (SWT) says: "Corruption has appeared throughout the land and sea by (reason of) what the hands of people have earned so He may let them taste part of (the consequence of) what they have done that perhaps they will return (to righteousness)" (The Holy Qur'an, 30:41). It explains that Islam sets clear basic principles in the CSR, even though the new CSR issues began in the $20^{\text {th }}$ century.

According to the sharia perspective, the CSR obligation is not only about meeting legal and moral ones, but also a strategy to make companies and people survive in the long term (Othman \& Thani, 2010). If the CSR is not implemented, there will be more costs to be borne by the company in the future. Conversely, if the company executes CSR well, actively works hard to balance the stakeholders' rights based on fairness, dignity, and justice, and ensures the fair distribution of wealth, it will actually benefit the company in the long term (Ibrahim, Marshall, \& Rahman, 2013; Mai, 2017; Manaf, Saad, Mohamad, Ali, \& Rahim, 2018). In contrast to conventional banks, it cannot be dichotomized separately between business and social orientation. The social activities of sharia banks are an additional value implicated in increasing long-term profitability and goodwill acquired in a positive image of the business works which may increase the stakeholders' confidence on the performance of Sharia Banks (Basri, Siti-Nabiha, \& Majid, 2016; Khediri, Charfeddine, \& Youssef, 2015).

The measurement used by the sharia banks to express their CSR is by using the Islamic Social Reporting (ISR) index which refers to the standard reporting of social performance of companies based on sharia emphasis on social justice related to the environment, the rights of minorities, and employees. There are five themes disclosing the ISR index, including financing and investment, products and services, employees, and also the community and environmental themes. Othman and Thani (2010); Othman, Thani, and Ghani (2009) developed the five themes by adding an additional theme called corporate governance.

Sharia and conventional banks are required to have a good performance, where its level is a commonly used financial performance measure covering several aspects: capital, quality of assets, management, earnings, and liquidity. The Sharia Supervisory Board Effectiveness (SSBE) will influence the Sharia Banks' financial performance and their CSR. This shows that the practice of good corporate governance (GCG) will result in higher financial performance and CSR (Brahmana, Brahmana, \& Ho, 2018; Mai, 2017).

Previous studies on the implementation of SSB /on the disclosure of CSR in Sharia Banks include those by Chariri (2008); Haniffa and Cooke (2005); Musibah and Alfattani (2014) used the Sharia corporate governance variable as a dependent variable with proxy characteristics such as the presence of Sharia Supervisory Board (SSB, or Dewan Pengawas Syariah (DPS) in Bahasa) and their skill composition within the organization. They stated the existence of the SSB and its membership composition had an influence on the level of CSR disclosure. Bukair and Rahma (2013) also examined the relationship of SSBSCORE (Sharia Supervisory Board-SCORE), number of board members, cross membership, secular education qualifications, reputation and expertise of SSB scholars on the CSR disclosed using ISR index in an annual report on the state Sharia Banks incorporated in the Gulf Council Countries (GCC) with bank size, financial performance using return on debt (ROD), and economic performance using growth domestic product (GDP) as the control variables. Based on the research of Bukair, Rahman and Abdullah (2013), the SSBSCORE had a significant effect on the CSR disclosure.

Musibah and Alfattani (2014) conducted a study to determine the effect of SSBE and Intellectual Capital (IC) on CSR among 36 Sharia Banks in GCC countries during a period of 2007-2011 with financial performance as a mediating variable. They found a positive influence on the relationship between SSBE and CSR. In contrast to the research by Bukair and Rahma (2013); Chariri (2008); Musibah and Alfattani (2014), Khoirudin (2013) showed that the SSB size variable did not have an influence on the CSR disclosure using ISR index of sharia banks in Indonesia. Khoirudin (2013) explained that the average of ISR disclosure by Sharia Banks was $55.20 \%$ with all Indonesian sharia banks as the population of the study. It is also claimed that the Sharia governance scores did not significantly influence the ISR disclosure, and it was concluded that there was still a lack of attention to the SSB on the ISR disclosure. By understanding the importance of the SSB responsibilities in the continuity of Sharia Banks, therefore, it is necessary to re-examine them. The researchers try to prove empirically the relationship between the SSB on the CSR disclosure of sharia banks in Indonesia with financial performance as its mediating variable.

\section{LITERATURE REVIEW}

\section{Stakeholder Theory}

Stakeholder theory describes any parties responsible for a company (Freeman, 2010). It claims that the company is not only an entity that operates for its own sake but also it should provide benefits for the stakeholders. Companies must maintain a good relationship with their stakeholders to accommodate their desires and needs, especially those who have power to resources' availability used for operational activities, e.g. labor market on the company's products and others. When the stakeholders control the important economic resources of the company, it will positively give satisfaction to the stakeholders' desires. 
Renneboog, ter Horst, and Zhang (2008) stated that the stakeholder theory emphasizes organization accountability which is expected to have a high financial performance. This theory states that a company should voluntarily disclose information on its environmental, social and intellectual performance besides its obligation such as financial statements to meet actual or recognized expectations by the stakeholders. Thus, this theory considers powerful stakeholders to be in such positions. The stakeholders are the main consideration for the company in disclosing and/ or not disclosing any information in the financial statements. According to Riahi-Belkaoui (2003), the ones included in the stakeholder category are shareholders, employees, customers, suppliers, creditors, government, and society. The whole potential of the company, both employees (as human capital), physical capital, as well as structural capital, must be used optimally to create valueadded for companies that can drive a company's financial performance and CSR for the benefit of the stakeholders (Dawkins \& Lewis, 2003; Robiyanto, Anggraeni, Nugraha, \& Lako, 2019; Robiyanto, Putra, \& Lako, 2019; Smith, 2011).

\section{Agency Theory}

Agency theory is a concept describing the relationship between principals and agents (Handriani \& Robiyanto, 2019). The principal party is the ones that regulate the other party, the agents, to perform all activities on behalf of the principles in their capacity as a decision-maker (Jensen \& Meckling, 1976). The agency theory assumes that the CEO (agent) has more information than the principals because the principals cannot observe the activities carried out continuously and periodically, resulting in asymmetrical information (Handriani \& Robiyanto, 2018). Agency problems on sharia banks force them to give more supervision by applying good corporate governance. Sharia banks implement their corporate governance by setting up a regulatory body known as the Sharia Supervisory Board (SSB) serving as the Sharia Compliance Bank as a manifestation of the principles of sharia compliance.

\section{Disclosure of CSR in A Sharia Perspective}

Social disclosure in a sharia perspective consists of full disclosure and social accountability (Basri et al., 2016; Haniffa \& Cooke, 2005; Santoso, Ningsih, \& Paramitha, 2017). The accountability concept is related to the principle of full disclosure aiming to serve the public interest. In Islam, the public has the right to know the operational effects of an organization on prosperity and whether they are advisable in Sharia requirements, and whether the established goals have been achieved (Othman et al., 2009). The goal of Sharia Social Reporting, according to toHaniffa and Cooke (2005), consists of two things. First, ISR is a way to show corporate accountability not only to God but also to society. Second, ISRs are used to improve the transparency of business activities by providing relevant information in the formation of conformity to the spiritual needs of decision-makers.

Othman et al. (2009) explained that the ISR contains social reporting standards set by Accounting and Auditing Organization for Sharia Institutions (AAOFI) which is then developed by the researchers based on the ISR items that should be disclosed by a Sharia entity. The ISR themes are similar to the ones in a conventional social disclosure, and the difference of ISR aims to serve the principles of Islamic business ethics and there are different items reported. Haniffa and Cooke (2005) proposed five themes of disclosure: finance and, investment, products, employees, and the environment.

\section{Sharia Supervisory Board (SSB)}

The application of Sharia compliance is performed by the Sharia Supervisory Board (SSB). The important role of the SSB in maintaining Sharia compliance is that they are responsible for overseeing services and products offered by banks and whether their operations have implemented and adhered to the Sharia principles. Sharia Supervisory Board is an element that creates a Sharia compliance assurance and is the main pillars in the implementation of Good Corporate Governance (GCG) of Sharia Banks. The more experienced SSB members will be able to improve business skills through collective decision-making and strategic decision action. Previous studies (i.e. Musibah and Alfattani (2014)) had used SSB Effectiveness (SSBE) as a measure of corporate governance. In Indonesia, the SSB is responsible for the National Sharia Board (Dewan Syariah Nasional (DSN) in Bahasa) and Bank Indonesia.

\section{Financial Performance}

The measurements of the bank's financial performance can be seen from the soundness of the bank. It is regulated based on "Act of the Republic of Indonesia Number 21 of 2008 Concerning Sharia (Islamic) Banking" 2008) and circular letter of Bank Indonesia No. 9/24/ DPbS on October $30^{\text {th }}$, 2007 on a rating system of commercial banks based on Sharia principles. There are several aspects to measure and assess a bank's performance, including the capital, asset quality, management, earnings, and liquidity.

\section{Capital}

The quantitative and qualitative assessment of capital factor is performed by appraising the components, such as the Adequacy of Minimum Capital Supplier Liability to the prevailing provisions; capital composition; future trend of KPMM covering productive assets classified as compared to bank capital; the ability of banks to maintain the need for additional capital derived from profits (retained earnings); bank capital plan to support business growth; access to sources of capital; and financial performance of shareholders to increase bank capital.

\section{Management}


One of the evaluations on management factors can be done by assessing these components which include calculating used net operational margin (NOM); general management; implementation of the risk management system; bank compliance with prevailing regulations and commitments to Bank Indonesia and/ or other parties.

\section{Earnings (Profitability)}

One of the quantitative and qualitative assessments approaches is to assess the following components: return on assets (ROA), return on equity (ROE), net interest margin (NIM), operating costs compared to operating income, operating profit development, portfolio composition of earning assets and income diversification, the implementation of accounting principles in revenue and expense recognition, and prospect of operating profit.

\section{Liquidity}

One of the quantitative and qualitative assessments approaches is to assess the following components: is to assess the following components: liquid assets less than one month compared with liquid assets less more one month, i-month maturity mismatch ratio, loan to deposit ratio (LDR), projected cash flow in three months; dependence on interbank funds and core depositors, policy and liquidity management (asset and liabilities management (ALMA)); the ability of banks to gain access to money markets, capital markets or other sources of funding, and stability of third party funds.

\section{HYPOTHESIS FORMULATION}

\section{The Influence of the Sharia Supervisory Board on CSR Disclosure}

Sharia Supervisory Board (SSB) is a fundamental distinction between the sharia and conventional banks and it directs, supervises and reviews activities of the Sharia Banks to ensure that their activities are in accordance with the sharia rules and principles expected by the society (Ousama \& Fatima, 2010; Wahyudi et al., 2018).

The SSB serves on several Sharia Banks to increase information disclosure because they can compare several reports to determine which one is the best in reporting them (Bukair \& Rahma, 2015; Haniffa \& Cooke, 2005). If sharia banks have a strong disclose, the SSB will consider following up more CSR information in the annual report. Based on these descriptions, a hypothesis can be formulated as follows:

H1: The Sharia Supervisory Board has a positive influence on CSR Disclosure of sharia banks in Indonesia.

\section{The Influence of the Sharia Supervisory Board on Financial Performance}

The existence of the Sharia Supervisory Board (SSB) helps companies to minimize agency problems due to a wide divergence of interests between the principals and the agents, so the financial performance of sharia banks would be better (Lestari, 2013). The SSB is established to charge and be responsible for monitoring and ensuring sharia bank activities to be in an accordance with the sharia principles and that they have implemented good corporate governance based on the applicable rules (Khoirudin, 2013). The SSB helps to supervise the policies or decisions in running and advising the bank management. A large number of members with diverse expertise of SSB could make the supervision of cross positions against any decision of the management to be better and so is the performance management. This would lead to an improved financial performance of Sharia Banks. The financial performance of sharia banks consists of several aspects including: capital, asset quality, liquidity, management, and profitability (earnings).

The approaches used in financial ratios are capital adequacy ratio (CAR), ROE, net operational margin (NOM), and financing deposit ratio (FDR). There were results indicating that there was a positive relationship between the good practice of corporate governance with the company performance (i.e. Handriani and Robiyanto (2019); Musibah and Alfattani (2014); Purnamawati, Yuniarta, and Astria (2017). Based on these descriptions, the second hypothesis that can be proposed is as follows:

H2: The Sharia Supervisory Board has a positive influence on the financial performance of sharia banks in Indonesia.

\section{The Influence of Financial Performance on CSR Disclosure}

Based on sharia perspectives described by Othman et al. (2009), companies must be willing to give full disclosure despite the fact whether the company makes a profit or not. However, Adefemi, Hassan, and Fletcher (2018); Othman and Thani (2010); Sunarsih and Ferdiansyah (2017) argued that firms with higher profitability would disclose information more widely than firms with low profitability. Like the obligation to deliver zakat in Islam, someone with more income is obliged to give zakat for social activities.

Companies with good financial performance will conduct a broader CSR. This is consistent with the stakeholder theory which states that the company is not the only entity that operates for its own sake, but it should be able to provide benefits to its stakeholders and it is believed that the more powerful stakeholders, the greater the company's efforts to adapt (Chariri, 2008). As an agent of the fund owner, a company must strive to generate high profitability. Therefore, they will be willing to reveal information more widely because they want to make a good image to the fund owners (Othman et al., 2009). Based on these descriptions, the third hypothesis can be formulated as follows: 
H3: Financial Performance has a positive influence on CSR disclosure

\section{Financial Performance Mediates Influence of Sharia Supervisory Board on CSR Disclosure}

Sharia Supervisory Board (SSB) as a form of a corporate governance implementation in sharia banks are able to influence the management decisions and it will also give an impact on the bank's financial performance. Based on the resource dependency theory, the SSB will influence financial performance and corporate social responsibility. This shows that the practice of corporate governance represented by the SSB will generate higher financial performance and corporate social responsibility. Their results showed that there was a positive relationship between good corporate governance and company performance (Mai, 2017; Musibah \& Alfattani, 2014).

The SSB is established to charge and be responsible for monitoring and ensuring sharia bank activities to be in an accordance with the sharia principles and that they have implemented good corporate governance based on the applicable rules (Bukair \& Rahma, 2013). The SSB helps to supervise the policies or decisions in running and advising the bank management. A large number of members with diverse expertise of SSB could make the supervision of cross positions against any decision of the management to be better and so is the performance management. This would lead to the improved financial performance of sharia banks and give a positive influence on CSR. Based on these descriptions, the fourth hypothesis that can be formulated is as follows:

H4: The financial performance mediates the relationship between the influences of the Sharia Supervisory Board on CSR Disclosure

\section{METHODOLOGY}

The population of this study was all Sharia Banks in Indonesia listed in Statistics Sharia Banking in the Financial Services Authority in the period of 2010-2016. The research period is chosen because, during 2010-2016, there is still a lack of attention by the Sharia supervisory board in terms of ISR disclosure for the sustainability of the Sharia Banks. A purposive sampling technique was used with the following criteria: (1) A Sharia Banks; (2) Disclosing CSR activities in the annual report; (3) Publishing the financial statements consistently and completely in an annual report (2010 - 2016). The data were analyzed using Structural Equation Modeling (SEM). The variables in this research are Return on Equity (ROE), Financing to Deposits Ratio(FDR), Capital Adequacy Ratio (CAR), and Net Operating Margin (NOM). According to (Nurhikmah, Winarsih, and Kusumaningtyas, 2018) ROE is a profitability ratio that demonstrates the bank's ability to earn a profit on a number of assets and equity, FDR is a ratio to assess the liquidity factor. CAR is a capital aspect to find out that the capital is sufficient to support long-term liabilities; meanwhile, NOM is a ratio to find out the asset ability in earning the profit.

\section{DISCUSSION / ANALYSIS}

\section{Direct Effect Test}

\section{The Influence of SSB on CSR Disclosure}

Based on Table 1, it shows that the SSB has a positive and significant influence on the CSR disclosure. This is indicated by the p-value of 0.037 , which is smaller than 0.05 . Therefore, the first hypothesis mentioning that the SSB has a positive influence on the CSR disclosure of sharia banks in Indonesia is supporting Bukair and Rahma (2015); Musibah and Alfattani (2014). The result of a direct effect test of SSB on CSR disclosure shows a positive and significant influence on CSR.

Table 1: Results of Direct Effect Test

\begin{tabular}{llllllll}
\hline & & & Estimate & S.E. & C.R. & P & Conclusion \\
\hline ROE & $<---$ & SSB & 2.897 & 1.142 & 2.538 & .011 & Significant \\
\hline FDR & $<---$ & SSB & -16.500 & 12.895 & -1.280 & .201 & Not significant \\
\hline CAR & $<---$ & SSB & -.301 & .434 & -.693 & .489 & Not significant \\
\hline NOM & $<---$ & SSB & 1.042 & .415 & 2.514 & .012 & Significant \\
\hline CSR & $<---$ & SSB & .029 & .014 & 2.087 & .037 & Significant \\
\hline CSR & $<---$ & ROE & -.001 & .002 & -.408 & .683 & Not significant \\
\hline CSR & $<---$ & FDR & .000 & .000 & 2.801 & .005 & Significant \\
\hline CSR & $<---$ & CAR & -.008 & .004 & -1.915 & .056 & Not significant \\
\hline CSR & $<---$ & NOM & -.010 & .005 & -2.215 & .027 & Significant
\end{tabular}

Source: Processed data.

\section{The Influence of SSB on Financial Performance}

The influence of SSB on financial performance consists of a measurement of ROE, FDR, CAR, and NOM. First, the result of the direct effect test shows that the influence of SSB on ROE can be indicated by the p-value of 0.011 which is less than 
0.05. This shows that ROE contributes positively and significantly to the influence of SSB on financial performance. Second, the result of the direct effect test showing the influence of SSB on FDR can be indicated by the p-value of 0.201 which is greater than 0.05 . However, this shows that FDR is not significant. Therefore, FDR contributes negatively to the influence of SSB on financial performance. Third, the result also shows that the p-value of CAR is 0.489 which is greater than 0.05. This means that CAR is not significant. Therefore, CAR contributes negatively to the influence of SSB on financial performance. The last measurement is NOM. The direct effect of NOM is shown by the p-value of 0.012 which is less than 0.05 . This shows that NOM has a positive and significant effect. Therefore, NOM contributes positively to the influence of SSB on financial performance. These findings support Handriani and Robiyanto (2019); Musibah and Alfattani (2014); Purnamawati et al. (2017).

\section{The Influence of Financial Performance on the CSR Disclosure}

The direct effect of financial performance on CSR disclosure consists of a measurement of ROE, FDR, CAR, and NOM. First, the result of the direct effect test shows that the influence of ROE on CSR disclosure can be indicated by the p-value of 0.683 which is greater than 0.05 . This shows that ROE is insignificant. Therefore, ROE does not contribute to the influence of financial performance on CSR disclosure. Second, the result of the direct effect test showing the influence of FDR on CSR disclosure can be indicated by the p-value of 0.005 which is smaller than 0.05 . This shows that FDR is significant on CSR disclosure. Therefore, FDR contributes positively to the influence of financial performance on CSR disclosure. Third, the result also shows that the p-value of CAR is 0.056 which is greater than 0.05 . This means that CAR is not significant. Therefore, CAR contributes negatively to the influence of financial performance on CSR disclosure. The last measurement is NOM. The direct effect of NOM is shown by the p-value of 0.027 which is less than 0.05 . This shows that NOM has a positive and significant effect. Therefore, NOM contributes positively to the influence of financial performance on CSR disclosure. These findings support Chariri (2008) and Othman and Thani (2010).

\section{Indirect Effect Test}

To understand whether the financial performance mediates the influence of SSB on the CSR disclosure, an indirect effect test was done. The financial performance consists of ROE, FDR, CAR, and NOM aspects. The result of the test can be seen in Table 2.

Table 2: Result of Indirect Effect Test

\begin{tabular}{lllll}
\hline Relation & Estimation & SE & CR & Conclusion \\
\hline $\mathrm{SSB} \rightarrow \mathrm{FP} \rightarrow \mathrm{CSR}$ & -0.017 & 0.013 & -1.308 & Not significant \\
\hline
\end{tabular}

Source: Processed data.

Based on Table 2, the Critical Ratio (CR) is $-1,308$ which is less than 1.96. The significant level of $\alpha=5 \%$ will show a significant relationship if the CR $>1.96$. Therefore, the results show that they do not mediate the influence of SSB on CSR disclosure. This can be concluded that the financial performance does not mediate the relationship between the influences of the SSB on CSR Disclosure. The summary of the direct and indirect effect tests shown in Table 3.

Table 3: Summary of Direct and Indirect Effect Tests Result

\begin{tabular}{lllll}
\hline & & & p - value & Conclusion \\
\hline ROE & $<---$ & SSB & .011 & Significant \\
\hline FDR & $<---$ & SSB & .201 & Not Significant \\
\hline CAR & $<---$ & SSB & .489 & Not Significant \\
\hline NOM & $<---$ & SSB & .012 & Significant \\
\hline CSR & $<---$ & SSB & .037 & Not Significant \\
\hline CSR & $<---$ & ROE & .683 & Significant \\
\hline CSR & $<---$ & FDR & .005 & Not Significant \\
\hline CSR & $<---$ & CAR & .056 & Significant \\
\hline CSR & $<---$ & NOM & .027 & \\
\hline
\end{tabular}

Based on the Table 3, it shows that overall, the SSB has a positive and significant influence on the CSR disclosure and financial performance does not have empirical support to mediate the relationship between the influence of SSB on the CSR disclosure. These findings don't support Bukair and Rahma (2015) and Othman and Thani (2010). This may happen because the purpose of SSB existence in Indonesian sharia banks is to comply with the Bank Indonesia's regulation and the Financial Service Authority's regulation.

\section{CONCLUSION}

Sharia Supervisory Board (SSB) has a positive influence on the CSR disclosure of Sharia Banks in Indonesia. This indicates that the main task of SSB was to oversee the daily operational activities of Sharia Banks whether they were based on sharia principles or not. The influence of SSB on the financial performance of Sharia Banks in Indonesia consists of the measurement of ROE, FDR, CAR, and NOM. Based on the results; it shows that SSB does not have any influence 
from the FDR and CAR, while ROE and NOM contribute positively. These results show that a sharia principlesbased GCG was implemented when the SSB gave a positive response to the stakeholders.

Meanwhile, financial performance consists of ROE, FDR, CAR, and NOM aspects. On the influence of financial performance to the CSR disclosure, it is indicated that ROE and CAR do not affect the financial performance on the CSR disclosure, while the FDR and NOM do. These results suggest that the Sharia Banks did need recognition from the public or the legitimacy of the community and should maximize their financial capabilities through the implementation of CSR activities. On the other hand, the financial performance proxied by the ROE, FDR, CAR, and NOM does not have empirical support to mediate the relationship between the SSB and the CSR closure of sharia banks in Indonesia.

\section{LIMITATION AND STUDY FORWARD}

For future studies, it is suggested that they may add quality assets as a proxy for financial performance and other variables in order to obtain better results. The GCG in the Sharia Banking Industry in the form of the Sharia Supervisory Board should discipline its regulation to oversee the activities to attract the interest of stakeholders, especially the public and investors to consider using the services of Sharia banking.

\section{ACKNOWLEDGMENT}

We thank the anonymous referees for their useful suggestions.

\section{AUTHORS CONTRIBUTION}

Winarsih conceived the study and was responsible for the design and development of the data analysis. Winarsihand Robiyanto was responsible for data collection, analysis, and data interpretation. Winarsih wrote the first draft of the article. Winarsih and Robiyanto wrote the revised version of the article.

\section{REFERENCES}

1. Act of the Republic of Indonesia Number 21 of 2008 Concerning Sharia (Islamic) Banking, (2008).

2. Adefemi, F., Hassan, A., \& Fletcher, M. (2018). Corporate governance disclosure in Nigerian listed companies. International Research Journal of Business Studies, 11(2), 67-80. https://doi.org/10.21632/irjbs.11.2.67-80

3. Basri, H., Siti-Nabiha, A. K., \& Majid, M. S. A. (2016). Accounting and Accountability in Religious Organizations: An Islamic Contemporary Scholars' Perspective. Gadjah Mada International Journal of Business, 18(2), 207-230. https://doi.org/10.22146/gamaijb.12574

4. Brahmana, R. K., Brahmana, R. K., \& Ho, T. C. F. (2018). Training and Development Policy, Corporate Governance, and Firm Performance. Gadjah Mada International Journal of Business, 20(1), 59-87. https://doi.org/10.22146/gamaijb.12995

5. Bukair, A. A., \& Rahma, A. A. (2013). The Influence of the Shariah Supervision Board on Corporate Social Responsibility Disclosure by Islamic Banks of Gulf Co-operation Council Countries. Asian Journal of Business and Accounting, 6(2), 65-104.

6. Bukair, A. A., \& Rahma, A. A. (2015). The Effect of the Board of Directors' Characteristics on Corporate Social Responsibility Disclosure by Islamic Banks. Journal of Management Research, 7(2), 506-519. https://doi.org/10.5296/jmr.v7i2.6989

7. Chariri, A. (2008). Organizational Culture and Financial Reporting Practice in an Indonesian Insurance Company. Paper presented at The 3th International Conference on Business and Management Research (ICBMR), Denpasar, Bali, Indonesia.

8. Dawkins, J., \& Lewis, S. (2003). CSR in Stakeholder Expectations: And Their Implication for Company Strategy. Journal of Business Ethics, 44(2), 185-193. https://doi.org/10.1023/A:1023399732720

9. Freeman, R. E. (2010). Strategic Management: A Stakeholder Approach. Cambridge: Cambridge University Press.

10. Handriani, E., \& Robiyanto, R. (2018). Investment opportunity and industrial growth in Indonesia. International Journal of Business and Society, 19(2), 295-312. http://www.ijbs.unimas.my/images/repository/pdf/Vol19-no2paper3.pdf

11. Handriani, E., \& Robiyanto, R. (2019). Institutional ownership, independent board, board size, and firm performance: evidence from Indonesia. Contaduría y Administración, 64(3), 1-16. http://doi.org/10.22201/fca.24488410e.2018.1849

12. Haniffa, R. M., \& Cooke, T. E. (2005). The impact of culture and governance on corporate social reporting. Journal of Accounting and Public Policy, 24(5), 391-430. https://doi.org/10.1016/j.jaccpubpol.2005.06.001

13. Ibrahim, Z., Marshall, A., \& Rahman, R. A. (2013). Islamic Social Disclosure (ISCR) of Malaysian Public Listed Companies: Empirical Findings. British Journal of Economics, Finance and Management Sciences, 7(1), 26-46.

14. Jensen, M. C., \& Meckling, W. H. (1976). Theory of the firm: Managerial behavior, agency costs and ownership structure. Journal of Financial Economics, 3(4), 305-360. https://doi.org/10.1016/0304-405X(76)90026-X 
15. Khediri, K. B., Charfeddine, L., \& Youssef, S. B. (2015). Islamic versus conventional banks in the GCC countries: A comparative study using classification techniques. Research in International Business and Finance, 33, 75-98. https://doi.org/10.1016/j.ribaf.2014.07.002

16. Khoirudin, A. (2013). Corporate Governance dan Pengungkapan Islamic Social Reporting pada Perbankan Syariah di Indonesia. Accounting Analysis Journal, 2(2), 227-232. https://doi.org/10.15294/aaj.v2i2.2919

17. Lestari, P. (2013). Determinants Of Islamic Social Reporting In Syariah Banks: Case Of Indonesia. International Journal of Business and Management Invention, 2(10), 28-34.

18. Mai, M. U. (2017). Mediation of CSR and Profitability on the Influences of GCG Mechanism to the Firm Value. Jurnal Keuangan dan Perbankan, 21(2), 253-264. http://jurnal.unmer.ac.id/index.php/jkdp/article/view/393

19. Manaf, N. B. A., Saad, N. B. M., Mohamad, N. E. A. B., Ali, I. B. M., \& Rahim, N. B. (2018). Determinants of Sustainable Growth Rate (SGR) By Using Zakon', S Model To Encounter With Shariah Compliance Requirements for Shariah Securities Compliance Firms in Malaysia. International Journal of Industrial Management, 4(4), 61-71.

20. Muharam, H., Anwar, R. J., \& Robiyanto, R. (2019). Islamic stock market and Sukuk market development, economic growth, and trade openness (the case of Indonesia and Malaysia). Business: Theory and Practice, 20, 196-207. https://doi.org/10.3846/btp.2019.19

21. Musibah, A., \& Alfattani, W. (2014). The Mediating Effect of Financial Performance on the Relationship between Shariah Supervisory Board Effectiveness, Intellectual Capital and Corporate Social Responsibility, of Islamic Banks in Gulf Cooperation Council Countries. Asian Social Science, 10(17), 139-164. https://doi.org/10.5539/ass.v10n17p139

22. Nurhikmah, F., \&Winarsih, W., \& Kusumaningtyas, M. (2018). The Influence of Sharia Supervisory Board and Intellectual Capital Towards Corporate Social Responsibility Disclosure with Financial Performance as The Mediation Variable (Empirical Study of Shariah Banking in Indonesia). Journal of Islamic Banking and Finance, 2(2), 174-188.

23. Othman, R., \& Thani, A. M. (2010). Islamic Social Reporting Of Listed Companies In Malaysia. International Business \& Economics Research Journal, 9(4). doi:https://doi.org/10.19030/iber.v9i4.561

24. Othman, R., Thani, A. M., \& Ghani, E. K. (2009). Determinants of Islamic Social Reporting Among Top ShariahApproved Companies in Bursa Malaysia Research Journal of Internatıonal Studies(12), 4-20.

25. Ousama, A. A., \& Fatima, A. H. (2010). Voluntary disclosure by Shariah approved companies: an exploratory study. Journal of Financial Reporting and Accounting, 8(1), 35-49. https://doi.org/10.1108/19852511011055943

26. Purnamawati, I. G. A., Yuniarta, G. A., \& Astria, P. R. (2017). Good Corporate Governance dan Pengaruhnya Terhadap Nilai Perusahaan Melalui Corporate Social Responsibility Disclosure. Jurnal Keuangan dan Perbankan, 21(2), 276-286.

27. Renneboog, L., ter Horst, J., \& Zhang, C. (2008). The price of ethics and stakeholder governance: The performance of socially responsible mutual funds. Journal of Corporate Finance, 14(3), $302-322$. https://doi.org/10.1016/j.jcorpfin.2008.03.009

28. Riahi-Belkaoui, A. (2003). Intellectual capital and firm performance of US multinational firms: A study of the resource-based and stakeholder views. Journal of Intellectual Capital, 4(2), $215-226$. https://doi.org/10.1108/14691930310472839

29. Robiyanto, R., Anggraeni, A. D., Nugraha, A. K. N. A., \& Lako, A. (2019). The Effect of Good Corporate Governance Mechanism on Firm Value of Indonesian Socially Responsible Firms. Quality: Access to Success, 20(173), 59-63.

30. Robiyanto, R., Putra, A. R., \& Lako, A. (2019). The effect of corporate governance and intellectual capital toward financial performance and firm value of socially responsible firms. Contaduría y Administración, 66(1), 1-29. http://dx.doi.org/10.22201/fca.24488410e.2021.2489

31. Robiyanto, R., Santoso, M. A., \& Ernayani, R. (2019). Sharia Mutual Funds Performance in Indonesia. Business: Theory and Practice, 20, 11-18. https://doi.org/10.3846/btp.2019.02

32. Santoso, N. T., Ningsih, R. M., \& Paramitha, R. P. (2017). Determinants of Islamic Social Reporting Disclosure: The Case of Jakarta Islamic Index. In R. Said, N. Z. M. Sidek, Z. Azhar, \& K. A. Kamarudin (Eds.), State-of-theArt Theories and Empirical Evidence (pp. 27-39). Singapore: Springer. http://doi-org443.webvpn.fjmu.edu.cn/10.1007/978-981-10-6926-0_2

33. Smith, R. E. (2011). Defining Corporate Social Responsibility: A Systems Approach For Socially Responsible Capitalism. (Master of Philosophy Thesis), University of Pennsylvania, Philadelphia. Retrieved from http://repository.upenn.edu/cgi/viewcontent.cgi?article=1009\&context=od theses mp

34. Sunarsih, U., \& Ferdiansyah, F. (2017). Determinants of the Islamic Social Reporting Disclosure. Journal of Islamic Economics, 9(1), 69-80. http://dx.doi.org/10.15408/aiq.v9i1.3771

35. Wahyudi, S., Nofendi, D., Robiyanto, R., \& Hersugondo, H. (2018). Factors affecting return on deposit (ROD) of sharia banks in Indonesia Business: Theory and Practice, 19, 166-176. https://doi.org/10.3846/btp.2018.17 